


\section{ITHAGINIS CRUENTUS.}

\section{Sanguine Francolin.}

Phasianus cruentus, Hardw. Linn. Trans, , vol. xiii. p. 237.

Sanguine Pheasant, Lath. Gen. Hist., vol. viii. p. 205.

Perdix cruentata, Temm. Pl. Col. 332.

Ithaginis cruentus, Wagl. in Isis, 1832, p. 1228.-Gray and Mitch. Gen. of Birds, vol. iii. p. 504, Ithaginis, sp. 1. -Cat. of Spec. and Draw. of Mamm. and Birds presented to Brit. Mus. by B. H. Hodgson, Esq. p. 126. - Blyth, Cat. of Birds in Mus, of Asiat. Soc. Calcutta, 241.-List of Birds in Brit. Mus. Coll., Part III. p. 31.

Francolinus cruentatus, Cuv. Règn. Anim., tom. i. p. 484.-Less. Traité d’Orn., p. 505.-Jard. Nat. Lib. Gallinaceæ, vol. ii. pl. 7.

Perdix cruentatus, Jard. Nat. Lib. Gallinaceæ, vol. ii. p. 90.

Phasianus Gardnerii, Hardw. Linn. Trans., vol. xv. p. 166, female.

Lophophorus Gardneri, Less. Man. d'Orn., tom. ii. p. 180.

Ithaginis Gardneri, Wagl. in Isis, 1832, p. 1228.

The Ithaginis cruentus is a gallinaceous bird peculiar to the great Himalayan range, and may be regarded as one of the finest species of the group inhabiting that region; it differs from them all in structure and also in the distribution of its colouring; the propriety therefore of Wagler's constituting it the type of a distinct genus is very apparent. So great is the dissimilarity of the sexes, that the late Major General Hardwicke, to whom we are indebted for our first knowledge of the species, described them as distinct, under the specific appellations of eruentus and Gardneri: the information he was enabled to furnish respecting it was very meagre, and I regret to say that up to the present time little more has been acquired. When speaking of the male, he says: "This fine species is a native of the Nepaul Hills, and it is to the liberal contributions of the Honourable Edward Gardner, Resident at the Court of Nepaul, that I am indebted for the opportunity of describing it." Of the female he remarks-

"This singular bird is a native of the Snowy Mountains north of the valley of Nepaul, and was procured through the zealous exertions of my friend Dr. Nathaniel Wallich, aided by the influence of the English Resident at Katmandoo (the Honourable Edward Gardner), without which no single article, of however little value, is obtainable from that jealous people the Nepaulese. It is the only subject of its kind obtained during Dr. Wallich's sojourning at Katmandoo, and from its scarcity at that place it may be deemed one of the rarities of the country."

The native habitat of the species has been more recently visited by Dr. Hooker, who has kindly furnished me with the following notes respecting it:-

"This, the boldest of the Alpine birds of its kind, frequents the mountain ranges of Eastern Nepaul and Sikkim at an elevation varying from 10,000 to 14,000 feet, and is very abundant in many of the valleys among the forests of Pine (Abies Webbiana) and Juniper. It seldom or ever crows, but emits a weak cackling noise. When put up it takes a very short flight and then runs to shelter. During winter it appears to burrow under or in holes amongst the snow, for I have snared it in January in regions thickly covered with snow at an altitude of 12,000 feet. I have seen the young in May. The principal food of the bird consisting of the tops of the pine and juniper in spring, and the berries of the latter in autumn and winter, its flesh has always a very strong flavour, and is moreover uncommonly tough; it was, however, the only bird I obtained at those great elevations in tolerable abundance for food, and that not very frequently. The Bhoteas say that it acquires an additional spur every year; certain it is that they are more numerous than in any other bird, and that they are not alike on both legs: I could not discover the cause of this difference, neither could I learn if they were produced at different times: I believe that five on one leg and four on the other is the greatest number I have observed."

The male has the forehead, lores, and the feathers surrounding the orbits black; crown of the head buff; crest dull grey, with a stripe of buff down the centre of each feather; back of the neck and upper surface dark grey, with a narrow stripe of buffy white, bounded on either side with a stripe of black, down the centre of each feather, the stripes becoming larger and more conspicuous as they proceed backwards, and with a tinge of green on those occupying the lower part of the back and the centre of the greater wingcoverts ; tail grey, fading into greyish white at the tip, the shafts white, and the basal three-fourths of the feathers broadly margined with blood-red; throat blood-red; ear-coverts black, striated with buffy white; lower part of the throat brownish black, with a stripe of greenish buff down each feather; sides of the neck buff; breast, sides of the abdomen and flanks very pale green with light shafts, and the feathers of the breast with a blotch of deep blood-red near the centre of either margin, giving the part the appearance of being stained with blood; centre of abdomen, thighs and vent dark brownish grey, striped with greenish white bounded by black; under tail-coverts deep blood-red, with a narrow line of pale yellow ending in a spatulate form at the tip, down the centre of each feather; orbits red; legs and feet deep red; base of the bill and nostrils red; tip of the bill black.

The female has the face, ear-coverts and throat rust-red; remainder of the plumage reddish brown, minutely freckled with black; tail dark brown freckled with black and buff; under surface similar, but redder than the upper.

The figures represent the two sexes of the natural size 


\section{$2 \mathrm{BHL}$ Biodiversity Heritage Library}

Gould, John. 1851. "Sanguine Francolin, Lthaginis cruentus [PI. 43]." The Birds of Asia 7(III), -. https://doi.org/10.5962/p.323388.

View This Item Online: https://www.biodiversitylibrary.org/item/122491

DOI: https://doi.org/10.5962/p.323388

Permalink: https://www.biodiversitylibrary.org/partpdf/323388

\section{Holding Institution}

Smithsonian Libraries

\section{Sponsored by}

Smithsonian Institution Libraries

\section{Copyright \& Reuse}

Copyright Status: Not in copyright

This document was created from content at the Biodiversity Heritage Library, the world's largest open access digital library for biodiversity literature and archives. Visit BHL at https://www.biodiversitylibrary.org. 